LLT, e-ISSN 2579-9533, p-ISSN 1410-7201, Vol. 20, No. 2, October 2017

$\boldsymbol{L} \boldsymbol{T}_{\text {Jounaut }}$

Language and Language Teaching Journal http://e-journal.usd.ac.id/index.php/LLT

Sanata Dharma University, Yogyakarta, Indonesia

\title{
TEACHERS' UNDERSTANDING OF LEARNER AUTONOMY IN INDONESIAN CONTEXTS: FINDINGS FROM HIGH SCHOOLS AND THEIR IMPLICATIONS
}

\author{
Dwi Agustina \\ Pekalongan University, Pekalongan, Indonesia \\ tina50@yahoo.co.id \\ DOI: doi.org/10.24071/1lt.2017.200206
}

received 29 June 2017; revised 1 August 2017; accepted 24 August 2017

\begin{abstract}
Learner autonomy has become one of the main topics in the current research and conferences in Indonesia. This suggests that learner autonomy has received more attention in Indonesian contexts. However, there has been no space for discussions about the meaning of learner autonomy from high school teachers' points of view. A multi-case study conducted by Agustina (2017) has found diverse understanding of autonomy as reported by Junior High School English teachers in Magelang Regency, Central Java, Indonesia. This paper discusses those teachers' understanding in a more detailed way along with the implications when the concept is understood differently. This paper supports Agustina's argument that the diversity in understanding and developing autonomy should be anticipated since teachers have different beliefs about autonomy. Referring to Agustina's findings this paper proposes the need to consider the consequences of allowing the presence of various understanding of learner autonomy particularly when it is set as an educational goal.
\end{abstract}

Keywords: learner autonomy, multi-case study, secondary schools

\section{Introduction}

With the increasing attention given to learner autonomy, conducting a research or publishing the work on this concept is one way to contribute to the local, national and international discussion within the field of learner autonomy. Similarly, this paper intends to contribute to the field of autonomy by discussing the meanings of autonomy as understood by English teachers in Agustina's (2017) study. With more and more practices of developing autonomy in Indonesian context, for example, Ardi's (2017) study, it is important to discuss what learner autonomy actually means and what teachers actually understand about it. However, there is not much discussion about the meaning of autonomy both in tertiary and secondary education in Indonesia.

This paper fills the gap in the discussion of learner autonomy by elaborating the most recent research findings. Agustina's study also shows that different ways in perceiving the concept of autonomy brought some implications on teachers' classroom practices. This paper looks at each of the meanings of learner autonomy as understood by teachers along with its implications. The paper continues by 
discussing the consequences of offering teachers great flexibility in understanding the concept of autonomy. Diverse understanding about learner autonomy may present challenges to the achievement of the educational goal of creating autonomous learners set by the government of Indonesia. Different understanding may lead to different practices of developing autonomy which can be either similar or dissimilar to what is required by the curriculum set by the government. This suggests that uniformity in understanding autonomy may initially be required before teachers begin implementing the curriculum which highlights the development of learner autonomy.

\section{Theory}

A number of definitions of autonomy can be found in the literature across the years although the earliest one was given by Holec $(1979$, p. 3) where he defined autonomy as "the ability to take charge of one's learning". With the emphasis on the word "ability", this definition focuses on what students can do to be responsible for the learning they are conducting. Holec explained further that the ability of an autonomous learner includes the ability to decide the learning objectives, materials, evaluation and progression. Little (1991, p. 4) proposes that autonomy is "a capacity-for detachment, critical reflection, decision-making, and independent action". Similar to Holec's definition, Little's definition covers learners' ability to make decisions in their learning while also touches learners' ability to act independently in learning. Apart from those definitions, Benson and Voller (1997) give the examples of various uses of the term 'learner autonomy'. They mention that autonomy can be seen as a situation (where the students learn independently without a teacher), as skills (which students can learn), as an inborn capacity, as an exercise of students' responsibility over their learning, and as the students' right to decide their learning (pp. 1-2). In this regard, learner autonomy has a range of meanings, covering not only skills, capacity, or responsibility, but also students' right for learning as well as the situation for their independent learning.

Dam (2000) emphasizes that the development of learner autonomy can be enhanced through the involvement of the learners in their learning. Dam adds that in autonomous learning, learners' task is to maintain an active engagement to the learning and the awareness about it. Benson (2011a) defines autonomy as "the capacity to take control of one's own learning" because, for him, using the term "control" eases the research on this concept as the term "control" is more open to investigate than the term "charge" or "responsibility" (p. 58). Huang and Benson (2013) describe control as power to select and decide the learning aspects and implement them. Benson (2013) also suggests that autonomy is reflected in autonomous language learning activities where learners have the control in their learning or particularly when they conduct outside-classroom language learning. Based on the definitions above, learner autonomy is mostly associated with learners' ability, responsibility, control, skills and engagement particularly in learning, in making decision and in acting or learning independently. Among those associations, the notion that autonomy includes learners' greater control in their learning has got huge agreement in the field (Benson, 2011b). Even so, 
autonomy remains a multidimensional construct (Benson, 2011b) and it is even a complex idea (Huang \& Benson, 2013). Thus, it is unlikely that we can use a sole definition to describe this concept.

\section{Theory Application}

With the availability of various definitions and descriptions of autonomy, those implementing the concept of autonomy may use different definition based on their own understanding of this complex concept. In Indonesian contexts, Agustina's (2017) study has found various understanding along with some misconceptions about the concept of learner autonomy. The concept of autonomy has been introduced in the new 2013 high school curriculum in Indonesia and Agustina studied how high school English teachers perceived this concept. The data were collected through the use of Likert scale questionnaire designed by Borg and Al-Busiadi (2012). Agustina also studied how English teachers' perceptions about learner autonomy affected classroom practices. The study employed 145 English teachers in Magelang regency, Central Java, Indonesia. Nine of the teachers were then purposefully selected for building a multi-case study about the implementation of learner autonomy in Indonesian context. Almost all respondents felt positive about the concept of autonomy as they expressed their agreement in the questionnaire that learner autonomy contributes to the success of students' language learning. However the multi-case study revealed that English teachers had various understanding about learner autonomy and thus the way they promoted it in the classroom varied considerably. Looking at Agustina's finding may help us to see the differences of understanding along with the implications for classroom practices. The followings are the findings of Agustina's study (p. 217) which reflects different beliefs and practices in developing learner autonomy in English classrooms in Indonesian contexts:

a. Teachers believed that smart learners could conduct autonomous learning.

Some teachers strongly believed in the ability of their smart students in learning autonomously. The basic idea is smart students are able to conduct autonomous learning. This suggests that these Indonesian teachers believed that learner autonomy is part of the inborn capacity that students brought even before they entered the schools. One of the teachers taught in a favorite school and the students in her school were good students who had passed elementary school examinations with good grades. Her students also entered the schools through highly competitive selection processes. She perceived these students as smart since they could understand her when she used English in her classrooms. Her teaching experiences convinced her that her students could conduct independent learning both inside and outside the classrooms. This belief led her to teach in such a way that more time was spent for students' autonomous or independent learning. As an example, after she introduced the learning topic in one of the lessons, she asked her students to work together in groups to search the materials in the internet and then present the materials in front of the class. The students thus became the learning resources for their friends. After each group presented the materials, they sent the materials to the teacher and the teacher would use those 
materials as the test materials in the following weeks. In this way, this teacher served more as a learning facilitator, manager of the class, as well as the evaluator of the students' learning progress. This finding brings an implication towards the practice of developing autonomy. By perceiving that smart students could learn independently, teachers may not recognize the needs for students to keep learning how to learn. Teachers may assume that students have already acquired the skills needed for autonomous learning activities. It is also possible that teachers perceive "not smart" students as having no ability to conduct autonomous learning. This affects the promotion of learner autonomy in the classrooms as teachers may only give independent learning tasks to those whom teachers perceive as smart students.

b. Teachers believed that when students learn autonomously, their workload would be alleviated.

A number of teachers believed that they would be more relaxed when students learned independently. When students are autonomous, they can learn without a teacher. Teachers thus believed that they only need to sit and observe the students. They assumed that they did not need to teach in front of the class anymore. They felt that the only times they should act was when students needed their helps. For them this meant the reduction of their work. I consider this kind of belief as an example of the misconception about the concept of learner autonomy in my study. Rather than having the reduction of the workload, teachers obviously have new roles and responsibilities in facilitating students' autonomy development. This has been specified by Gremmo and Riley (1995) that teachers have to acquire new professional skills to act as a learning facilitator, helper, and counselor. This finding suggests the lack of understanding of teachers' roles in an autonomous class. Teachers should be made aware of their new roles because developing autonomy in Indonesian context is a new task in which teachers may need some training. Without having sufficient understanding about learner autonomy, there is a risk that teachers let students learn the learning materials independently without proper guidance and monitoring.

c. Teachers believed that providing information to students would provide students with skills needed for independent learning.

Some other teachers believed that it was necessary for them to teach the students how to learn independently. Holding this belief, teachers guided their students on what and how to do a particular task. In this sense, teachers perceived autonomy as learned skills. Students could acquire the skills in the classrooms and then apply the skills for outside classroom learning activities. As teachers perceived autonomy as learned skills they may consider the need to be autonomous themselves before teaching their students the skills for conducting autonomous activities. Those who did not perceive themselves as autonomous may feel hesitate in teaching students to be autonomous. This becomes something to consider when teachers are required to develop autonomy in their learners. 
d. Teachers believed that students could complete out of class learning tasks such as homework.

Some teachers found that each of the tasks given to students could be accomplished well. This made the teachers believe that students had the capability to learn and work independently at home. Besides, teachers believed that students were responsible in completing the task and finding ways to do it. Therefore, teachers often gave homework after the lesson. The finding suggests that teachers see learner autonomy as the capacity to complete the task alone. Learner autonomy was also seen as students' responsibility to handle the tasks by using the resources they found themselves outside the class. The homework that teachers give can also be seen as an exercise for students' responsibility. However, the more autonomy students need to develop does not mean the more homework they have to complete and this should be made clear to the teachers.

e. Teachers believed that autonomous learners could make decision over classroom materials, group sizes and learning activities.

Based on their teaching experiences, teachers found that students could decide the materials to learn, the learning activities to do, and the size of groups when they were about to work with their peers. The teachers perceived their students as having high level of autonomy. Teachers could share the control over the learning materials and activities with their students. Learner autonomy in this regard was closely associated with learners' right to direct their learning. Based on this finding, it seems that being autonomous means having the ability to decide what to learn and how to learn. Seeing autonomy in this way may challenge teachers' own capability in mastering the learning materials. When students have the ability to select what and how to learn, teachers may need to be ready to facilitate students' learning. Students may come with a completely new topic for the teacher and the teacher has to be ready to discuss this when students bring the topic in the class. The key to autonomy development for this kind of learner autonomy is thus teachers' readiness and openness to cope with the new learning materials and activities

\section{Conclusion}

The findings of the study reflect the notion that the concept of autonomy is complex. There are various meanings of autonomy both in practice and in theory. Benson and Voller's (1997) theory has been reflected in Agustina's (2017) study findings where autonomy is perceived differently: as inborn capacities, as situation when students learn alone, as learned skills, and as students' capability and responsibility in completing the task. The implications coming with these varied understanding of autonomy can be seen in the way learner autonomy is promoted as discussed above. Allowing teachers to promote autonomy based on their own understanding about the concept seems to be the fair policy in the light of respecting teacher autonomy in enacting their teaching practices. However, it is necessary to set the boundary on what is considered as a misconception about the concept of autonomy and what is not. The misconceptions about learner autonomy should be minimized by providing sufficient information about what learner 
autonomy means, what autonomy covers, what roles teachers should take in developing learner autonomy and how to promote autonomy in their classrooms. The findings of Agustina's (2017) study above also reflect the need for teacher professional development activities particularly prior to implementing the curriculum which supports the development of learner autonomy. Professional development activities can help teachers to modify their beliefs about autonomy especially those which are not in line with the principles for promoting learner autonomy in classrooms. Finally, it is also necessary to consider the present challenges when teachers hold a particular belief about learner autonomy so that their belief does not limit the promotion of autonomy in their classrooms.

\section{References}

Agustina, D. (2017). A complex system of teachers' beliefs and practices in developing learner autonomy in Indonesian junior high school contexts: A mixed-methods study (Doctoral thesis, Victoria University of Wellington, New Zealand). Retrieved from http://researcharchive.vuw.ac.nz/handle/10063/6351

Ardi, P. (2017). Promoting learner autonomy through Schoology m-learning platform in an EAP class at an Indonesian university. Teaching English with Technology, 17(2), 55-76.

Benson, P. (2011a). Teaching and researching autonomy $\left(2^{\text {nd }}\right.$ ed.). Harlow: Longman.

Benson, P. (2011b). What's new in autonomy? JALT, 15-17.

Benson, P. (2013). Learner autonomy. TESOL Quarterly, 47(4), 839-843. https://doi.org/10.1002/tesq.134

Benson, P. \& Voller, P. (1997). Introduction: Autonomy and independence in language learning. In P. Benson \& P. Voller (Eds.), Autonomy and independence in language learning (pp. 1-12). New York: Longman.

Borg, S. \& Al-Busaidi, S. (2012). Learner autonomy: English language teachers' beliefs and practices (ELT Research Paper 12-07). London: British Council.

Dam, L. (2000). Evaluating autonomous learning. In B. Sinclair, I. McGrath, \& T. Lamb (Eds.), Learner autonomy, teacher autonomy: Future directions (pp. 48-59). Harlow: Pearson Education Limited.

Gremmo, M.-J., \& Riley, P. (1995). Autonomy, self-direction and self access in language teaching and learning: The history of an idea. System, 23(2), 151164. https://doi.org/10.1016/0346-251X(95)00002-2

Holec, H. (1979). Autonomy and foreign language learning. Strasbourg: Council of Europe.

Huang, J., \& Benson, P. (2013). Autonomy agency and identity in foreign and second language education. Chinese Journal of Applied Linguistics, 36(1), 7-28. https://doi.org/http://dx.doi.org/10.1515/cjal-2013-0002

Little, D. (1991). Learner autonomy 1: Definitions, issues and problems. Dublin: Authentik. 